\title{
Pbilaccolilus sagatai sp.n. from the Bewani Mountains of Papua New Guinea \\ (Coleoptera: Dytiscidae: Laccophilinae)
}

\section{Pbilaccolilus sagatai sp.n. с гор Бевани, Папуа Новая Гвинея (Coleoptera: Dytiscidae: Laccophilinae)}

\author{
M. Balke ${ }^{1}$, S. Surbakti ${ }^{2}$, L. Hendrich ${ }^{1}$ \\ М. Бальке ${ }^{1}$, С. Сурбактиㄹ, $\Lambda$. Хендрих ${ }^{1}$
}

\footnotetext{
${ }^{1}$ SNSB-Zoologische Staatssammlung München, Münchhausenstrasse 21, 81247 München, Germany. E-mail: balke.m@snsb.de

${ }^{2}$ Suriani Surbakti, Department of Biology, Universitas Cendrawasih, Jayapura, Papua, Indonesia.
}

KEY WORDS: Coleoptera, Dytiscidae, Philaccolilus, new species, Papua New Guinea, lotic species

КЛЮЧЕВЫЕ СЛОВА: Coleoptera, Dytiscidae, Philaccolilus, новый вид, Папуа Новая Гвинея, виды текучих вод

ABSTRACT. Philaccolilus sagatai sp.n. is described from the Bewani Mountains of Papua New Guinea. The lotic species was collected from sandy banks of a lowland rainforest stream. Important species characters (median lobe, colour pattern, microreticulation of the pronotal and elytral base, and hind margin of sternum 5 and 6) are figured. Altogether 13 species of the genus are now known from New Guinea.

РЕЗЮМЕ. С гор Бевани, Папуа Новая Гвинея, описан новый вид Philaccolilus sagatai sp.n. Он собран на песчаном берегу ручья в равнинном дождевом лесу. Проиллюстрированы основные диагностичекси признаки нового вида - эдеагус, окраска, микроскульптура переднеспинки и основания надкрылий, задний край 5 и 6 стернитов брюшка. Остальные 13 видов этого рода известны так же из Новой Гвинеи.

\section{Introduction}

The strictly running water diving beetle genus Philaccolilus Guignot, 1937, was recently revised by Balke et al. [2000]. It currently contains 12 species that are endemic to mainland New Guinea [Nilsson, Hájek, 2018]. These beetles are the only diving beetles in New Guinea that are adapted to habitats along river and stream margins with strong current. Several species were therefore recently used for population genomic studies as a test case for the investigation of the population structure of little studied invertebrates across high- ly structured tropical landscapes [Lam et al., 2018]. That paper suggested lineage idiosyncratic population structure in the studied species, and also suggested presence of cryptic species.

Here, we report the discovery of a rather conspicuous new Philaccolilus species from the hitherto unexplored Bewani Mountains in the northwest of Papua New Guinea.

\section{Methods}

The beetles were studied with a Leica MZ 12.5 stereo microscope at 10-100x. Drawings were produced with a camera lucida, sketched with pencil on paper first, photographed and digitally inked using an iPad Pro and the Concepts as well as MediBang Paint APPs. The plates were assembled in MS Powerpoint v 15.41 for Mac. Images of the habitus was taken with a digital imaging system, composed of a Canon 5DS camera with Nikon bellows, a Thorlabs iris, and 5-20x ELWD Plan Apo objectives attached to a Mitutoyo focus lens. Image stacks were generated using the Stackmaster macro rail (Stonemaster), and images assembled with the computer software Helicon Focus $4.77^{\mathrm{TM}}$.

This study is part of a capacity building and training program in aquatic invertebrate research between SNSBZoologische Staatssammlung München (ZSM) and the Universitas Cendrawasih in Jayapura, Papua. It is based on a MoU signed 25. May and 13. June 2010 by both parties, and is being continued with a renewed MoU and cooperation agreement pending.

How to cite this article: Balke M., Surbakti S., Hendrich L. 2018. Philaccolilus sagatai sp.n. from the Bewani Mountains of Papua New Guinea (Coleoptera: Dytiscidae: Laccophilinae) // Russian Entomol. J. Vol.27. No.4. P.363-365. doi: 10.15298/rusentj.27.4.02 


\section{Results}

Philaccolilus sagatai Balke et Hendrich, sp.n. Figs 1-7.

LIFE SCIENCE IDENTIFIER. Registered in Zoobank (www.zoobank.org) as urn:1sid:zoobank.org:pub:D1BC9A99BAD9-497D-95FF-D4D88BDEC6FD

MATERIAL. Holotype $\sigma^{7}$ (ZSM) "Papua New Guinea: Sandaun, Bewani Stn., stream@base of Bewani Mts, 200-300 m, 12.iv.2006, nr. 03.05.130S 141.10.227E, Balke \& Sagata (PNG 37)" / "M. Balke 1353".

TYPE LOCALITY. Papua New Guinea: Sandaun, Bewani Mountains.

DIAGNOSIS. The smallest species in the genus, with orange head, dark pronotum and conspicuous contrasting yellowish pattern on otherwise dark elytron (Fig. 1).

DESCRIPTION. Length of beetle $4.1 \mathrm{~mm}$, total length of beetle without head $3.9 \mathrm{~mm}$, greatest width of beetle $2.2 \mathrm{~mm}$.

Colour (Figs 1-2). Antenna, fore- and middle legs yellowish, hindlegs dark orange or reddish. Head dark orange. Pronotum black; anterior angle and margin backwards up to its middle dark orange. Elytron black; with contrasting yellowish pattern: a broad basal band that reaches the anterior and lateral elytral margin but not the suture; a broad postmedial band that almost reaches the lateral margin and does not reach the suture; and an apical spot connected to hind angle and suture. Venter blackish to rufous.

Sculpture and punctation. Dorsum with fine, widely spaced punctures (Figs 3-4). Head and pronotum (Fig. 3) with comparably regular polygonal microreticulation, somewhat faint on frons and clypeus. Elytron with slightly more impressed microreticulation of more transversal polygonal meshes.

Male. Protarsomeres 1 to 3 ventrally with transverse rows of stalked adhesive setae, only row on tarsomere 3 slightly sinuate, less than 10 setae per row. Sternum 6 broadly truncate apically, with subtle convexity in the middle (Fig. 7). Median lobe of aedeagus typical for the genus, simply curved and without conspicuous structure; tip in ventral view comparably broadly rounded (Figs 5-6).

Female. Unknown.

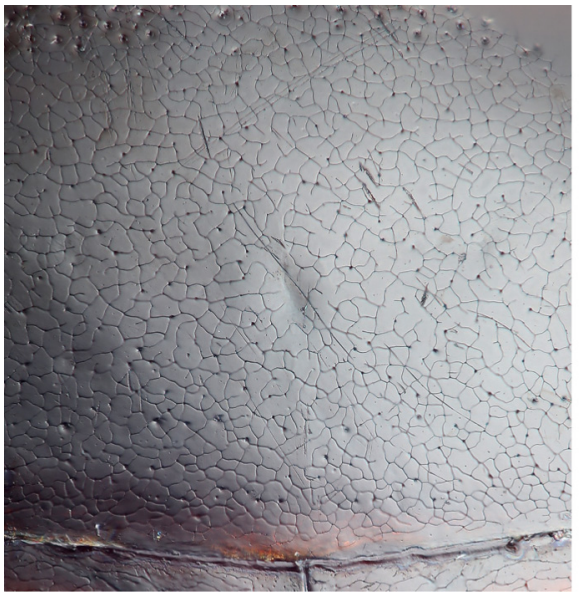

3

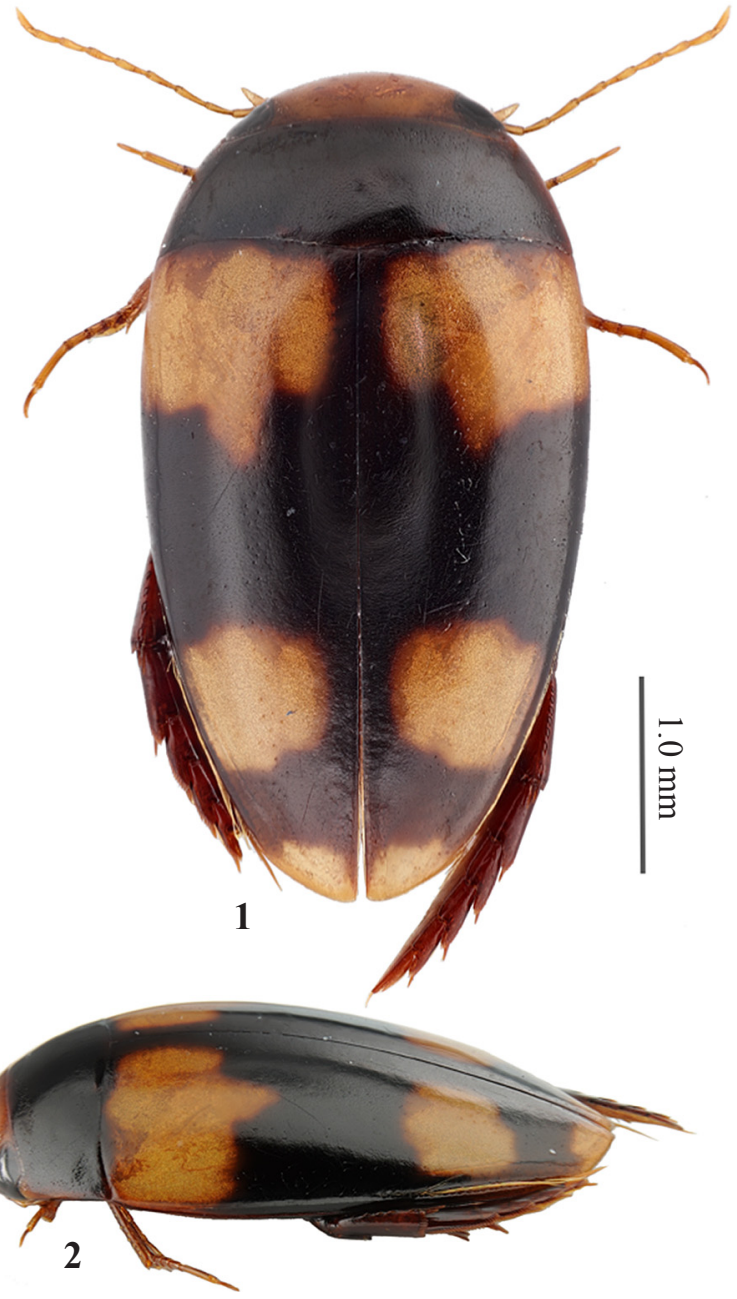

Figs 1-2. Philaccolilus sagatai sp.n.: habitus, illustrate colouration of dorsal surface: 1 - dorsal view; 2 - dorsolateral view.

Pис. 1-2. Philaccolilus sagatai sp.n.: внешний вид, окраска дорсальной поверхности: 1 - сверху; 2 - сверху и сбоку.

Figs 3-7. Philaccolilus sagatai sp.n.: 3-4 - microreticulation of the dorsal surface (3 - pronotal base; 4 - elytral base in sutural area); 5 - median lobe of aedeagus, lateral view; 6 - tip of median lobe of aedeagus with higher magnification, dorsal view; 7 - hind margin of sternum 5 as well as sternum 6 , ventral view.

Рис. 3-7. Philaccolilus sagatai sp.n., 3-4 - микроскульптура дорсальной поверхности (3 - основание переднеспинки; $4-$ основание надкрылий в области шва); 5 - медиальная лопасть эдеагуса, сбоку; 6 - вершина медиальной лопасти эдеагуса при большем увеличении, сбоку; 7 - задний край 5-го и 6-го стернитов брюшка, снизу. 
ETYMOLOGY. Named after the species' discoverer, Katayo Sagata, currently at the University of Papua New Guinea in Port Moresby. The specific epithet is a substantive in the genitive case.

AFFINTIES. The species is immediately recognizable based on its small size and lacking yellow spots in the middle of elytron but with broad yellow bands on base and apex of elytron.

DISTRIBUTION. Only known from the Bewani Mountains in Sandaun Province, Papua New Guinea.

HABITAT. Collected from the sandy banks of a lowland stream.

Modified Key to the SPecies of Philaccolilus [Balke et al., 2000]

$2^{\prime}$ change "Smaller, TL $=4.3$ to $5.8 \mathrm{~mm} . . . "$ to "Smaller, TL $=4.1$ to $5.8 \mathrm{~mm}$..."

run to option 7, and introduce:

7" Elytron without medial-discal and postmedial-subsutural spots .... P. sagatai sp.n.
ACKNOWLEDGEMENTS. This work was supported by DFG BA2152/19-1 and 19-2 to M. Balke. Funding has also been provided by the UK DARWIN INITIATIVE project "Training the next generation of PNG conservation biologists" to Alan Stewart.

\section{References}

Balke M., Larson D., Hendrich L., Konyorah E. 2000. A revision of the New Guinea water beetle genus Philaccolilus Guignot, stat. n. (Coleoptera, Dytiscidae) // Deutsche Entomologische Zeitschrift. Vol.47. No.1. P.29-50.

Lam A., Toussaint E.F., Kindler C., Van Dam M.H., Panjaitan R., Roderick G.K., Balke M. 2018. Stream flow alone does not predict population structure of diving beetles across complex tropical landscapes // Molecular ecology. Vol.27. No.17.P.35413554.

Nilsson A.N., Hájek J. 2018. A world catalogue of the family Dytiscidae (Coleoptera, Adephaga). 304 pp. Internet version 31.I.2018. Available from: http://www.waterbeetles.eu. 